\title{
Elements Enhancing the Use of Mobile Phone Money Services: A Case of Homa Bay Region, Kenya
}

\author{
Odoyo Collins Otieno ${ }^{1, *}$, Samuel Liyala ${ }^{1}$, Benson Charles Odongo ${ }^{2}$, Silvance Abeka $^{1}$ \\ ${ }^{1}$ School of Informatics and Innovative Systems, Jaramogi Oginga Odinga University of Science and Technology, Bondo Town, Kenya \\ ${ }^{2}$ Department of Special Needs Education and Early Childhood Development, Jaramogi Oginga Odinga University of Science and \\ Technology, Bondo Town, Kenya
}

Copyright $\subset 2016$ by authors, all rights reserved. Authors agree that this article remains permanently open access under the terms of the Creative Commons Attribution License 4.0 International License

\begin{abstract}
The history of mobile payments is more than 10 years old and mobile money services in various countries such as Finland are still relatively unpopular, even though consumers have shown clear interest towards mobile money. The Mobile phone banking idea was initially born out of the intention to reach the unbanked poor. There exist a spectacular mobile phone money service divide, highly skewed against the rural population. The study therefore, established mobile phone elements enhancing mobile money services, in Homa Bay Region. A sample size of 48 participants for semi-structured interviews, focus group discussion and participant observation was used. The data for the study was both primary and secondary. Interview was the main tool for primary data collection, supported by focus group discussion and participant observation, while secondary data was obtained from online journals, books and Daily Newspapers. Data was analyzed using thematic analysis. The study established that remittances had a positive influence on mobile phone money use, while lack of National Identification cards as well as lack of information by some users had a negative influence on mobile phone money use in the study area.
\end{abstract}

Keywords Mobile Phone Money, Mobile Phone Users, Homa Bay Region, Ndhiwa, Rangwe

\section{Introduction}

The history of mobile payments is more than 10 years old and mobile money services in various countries such as Finland are still relatively unpopular, even though consumers have shown clear interest towards mobile money. In the U.S., a study [1] to better understand Americans' attitudes towards privacy in new transaction systems commissioned a nationwide, telephonic (wireline and wireless) survey of 1,200 households, focusing upon the ways that mobile money systems are likely to share information about consumers' purchases. The study established that Americans overwhelmingly oppose the revelation of contact information such as; phone number, email address, and home address, to sellers when making purchases with mobile money systems. Furthermore, an even higher level of opposition existed to systems that track consumers' movements through their mobile phones. This is an indication that consumers are not comfortable having their information shared. They would therefore strongly resist any innovation that tends to propagate this.

\section{Literature Review}

According to Mallat, [2] it is important to differentiate between mobile payments and mobile banking services. The researcher established that mobile banking services are based on the bank's own legacy systems and offered for the bank's own customers. Mobile banking services utilise the mobile devices such as mobile phone or Personal Digital Assistant (PDA) as a delivery channel or intermediary between the conventional banking account and the final beneficiary of the financial transaction such as a merchant with electronic Point of Sales (POS). It is an evolution of the bank's legacy from 'traditional brick and mortar, which are the physical branches where most interactions taking place are face to face, to "click and mortar" where multichannel delivery approach involving the use of physical branches and ICT, and finally to "click" where most of the transactions are driven by ICT [3]. Mallat, [2] explored consumer adoption of mobile money using the diffusion of innovations theory. He further, notes that mobile money has offered as new payment services to a retail market which is characterized by: a multitude of competing providers such as banks and telecom operators; two different and demanding groups of adopters - consumers and merchants whose critical mass in terms of adopting the system is essential for the success of the service; and challenges regarding standardization and compatibility of different payment systems. This study however focused 
extensively on mobile banking and mobile payments as the main elements of mobile money. The study failed to establish the perception of users on the two mobile money elements. Also it failed to find out if there are other elements of mobile money that the users exploit. Further, this study uitilised Rodgers model of "diffusion of innovation theory"

Another study conducted by Comninos and Esselaar [4] analysed data collected from an e-Access and Usage Household Survey across 16 African countries with a representative sample in all but 2 countries which highlighted that more people had mobile phones compared to bank accounts. Their analysis established that, amongst the unbanked respondents, between $41.2 \%$ - $69.8 \%$ indicated lack of a regular income being the main obstacle, compared to perceived high banking costs $(0.2 \%-20.7 \%)$ or perceived inability to qualify for a bank account $(0.2 \%-$ $21.8 \%$ ). In all countries, both domestic and international remittances played a role in supporting households with informal channels of money transfer. Airtime transfers were also common across all countries, usually as a favour to friends or family and in a few instances as payment for goods or services. This study adopted household survey and established that both domestic and international remittances play a crucial role with informal channels of money transfer. This study introduced another element of mobile money which is money transfer. The study however failed to explore the users' perceptions on the elements of money transfer in general. It also did not explore whether there were other elements of mobile money in addition to mobile money remittance.

A survey by Okoth [5], conducted in Kenya on M-Pesa, established a number of factors on mobile phone use. First it established that, more than half of M-Pesa users use M-Pesa primarily to send and receive money. This means that the element of mobile phone money in this case is, as a means of sending and receiving money (remittance). Secondly, the survey established that 21 percent used M-Pesa for storing money. This means that the element of mobile phone money in this case is a store of money (saving). However, the survey further, established that less than 1 percent of accounts had balances of more than Kshs. 1,000 (US \$13). An audit the Kenyan government on M Pesa in August 2009, further, established that, the average balance on M - Pesa accounts was only US \$2.70. The survey also found that 52 percent of customers use the service on a monthly basis, suggesting that customers were yet to incorporate $\mathrm{M}$ - Pesa use into their daily lives [5], and the use was dominated by sending and receiving money as well as storing money (saving). The key elements of mobile money that this study established are remittance and saving money. This study failed to capture if mobile money users' had other mobile money elements.

Another study by Morawczynski [6] cites that M-PESA is used for "livelihood strategies" and that such "strategies helped residents to cope with and recover from stresses and shocks." The study was based on the previous ethnographic mixed method surveys in Kibera with additional work in the village of Bukura in Western Kenya. Remittances via M-Pesa were found to typically flow from urban to rural, with peaks during planting seasons, when farming inputs were needed, harvest seasons when additional labor was needed, and the so called "hunger season", when food stocks run low. This is typical of almost all Kenyan rural communities with agricultural rural communities taking the lead. Even though this study was based on ethnographic mixed method, it mainly focused on remittance via M-Pesa from urban to rural communities. This study also brought strongly the mobile money element of remittance. Even though it adopted ethnography survey, this study however, failed to look extensively at users' perceptions on the various elements of mobile phone money utilization as it only extensively discussed only one.

\section{Materials and Methodology}

Qualitative research technique was used because it is appropriate to help understand the dynamics of this study subject area. Ethnography research design was adopted based on its usefulness and appropriateness for this particular study. Ethnography, emerging from anthropology, and adopted by sociologists, is a qualitative methodology that lends itself to the study of the beliefs, social interactions, and behaviors of small societies, involving participation and observation over a period of time, and the interpretation of the data collected [7]. It is very time consuming type of research, however, its main benefit is its depth, and therefore the contribution of rich insight to the subject being studied. One weakness is that it lacks breadth, as the focus is typically on one particular situation or phenomenon, leading to a criticism of lack of generalizability [8]. Also, the main data collection technique is participant observation [9].

The study area was Homa Bay Region, comprising of Homa Bay Town, Ndhiwa and Rangwe sub counties, in Homa Bay County in the Republic of Kenya. The area is located in South Western Kenya along Lake Victoria where it boarders Mbita, Suba sub counties, Nyatike and Rongo subcouties of Migori County, and Karachuonyo sub county in Homa Bay County, and Kisumu County to the lake.

Semi-structured interview guide, focus group discussion guide and participant observation, were used as instruments of data collection that reached a total of 48 study participants. Informants responded to interview questions, participated in focus group discussions and observation by the researcher as well as capturing the voices of the respondents through a tape recorder that were later transcribed verbatim.

\section{Results}

The study found out that a number of elements of mobile phone money are already being used in the study area but not very common. It was in Homa Bay Town Sub County where 
the usage were to a reasonable level compared to Ndhiwa and Rangwe where the usage of these elements were very low.

\subsection{Sending and Receiving Money}

Sending and receiving money is the most common element of mobile phone money in the entire study area. In all the three sub counties that the researcher conducted the study namely Homa Bay Town, Rangwe and Ndhiwa, it was quite clear that this element was common to the youths as well as the old, to the rich as well as the poor, to the literate, as well the illiterate and to the people in the urban areas as well as the people in the rural areas. An interview conducted in Rangwe market center with a participant, found out that sending money to friends and relatives in other places as well as receiving money using mobile phone money was very common as can be seen from the words of the participant.

"This is the innovation that has really transformed how we go around our daily activities that revolves around sending and receiving money to and from others. In the past we would have to travel all the way to banks in Homa Bay Town to deposit cash for those who need it from us, or send as parcel to friends and relatives, which was really risky. Most of the people used to lose cash from time to time but when M-Pesa came, this has been a problem of the past... we just thank God for this"

The same stake was echoed in Homa Bay Town and Ndhiwa sub counties. An interview conducted in Homa Bay Town specifically, on the use of mobile phone to send money or receive money from friends and relative, showed popularity of this element as stated by the respondent;

"Surely, if you are not on M-Pesa, which technology, are you using to send or receive money to and from friends and relatives... this technology can easily help you, when you find yourself in crisis and needs cash urgently from your friends or relatives. I have soughed myself out in circumstances that I didn't believe I would find a way out, just because of M-Pesa."

Further, FGDs conducted in all the three sub counties also found the same results. Mobile money, especially Safaricom's M-Pesa, has become very popular because of the sending and receiving money that is very popular in users' perception.

\subsection{Buy Airtime}

Buying airtime was found by the researcher to be mainly common in towns and urban centers, and not rural settings. In rural parts of Rangwe and Ndhiwa sub counties, the researcher found out that very few people were aware that they could easily buy airtime for making calls, directly from their mobile phones when they had "money value" within their phones. Participant $\mathrm{X}$, in Ndhiwa appeared more surprised when the researcher informed her that she could actually purchase airtime from her mobile phone directly as long as she was registered on any of the mobile phone money services available to customers in Kenya. This was indeed strange to her;

"Stop taking me for a ride... you think I don't know all the uses of a mobile phone? A mobile phone cannot be used to buy airtime... that take to those who can be easily deceived but not me... If you need to buy airtime and you have money in your M-Pesa, you have to look for M-Pesa agent, withdraw money to get cash that you can use to buy airtime from any shop."

The researcher found this statement quite interesting, but that was the position in most of the rural parts of the study area. FGDs that were done in the two sub counties namely Ndhiwa and Rangwe, had mixed reactions, with just a handful of participants being aware that they could actually buy airtime directly from their phones when they have mobile money in their phones. A greater majority, just like participant X, were not aware at the time of study that it was in deed possible to buy airtime in their mobile phone if they had mobile money in their mobile phones.

\subsection{Mobile Banking}

Mobile banking was common in among the young generation and the educated who tended to be wealthier. From observation, most of those who spoke positively about mobile banking were majorly in urban centers. Most of them were also relatively young in age.

However, the interview conducted in both Ndhiwa and Rangwe found out that mobile banking was much unpopular in the rural parts of Ndhiwa and Rangwe Sub Counties. A participant for interview conducted in the remote part of Rangwe Sub County did not believe that his money could be safe when banked through mobile phone money as indicated;

"I am not comfortable banking my money or receiving my money from my bank account using mobile phone... I do not trust this technology. How can I trust that my money is safe and has been sent to my bank account?"

\subsection{Pay Bill}

Pay bill element was found to be in use in a lower scale in both Ndhiwa and Rangwe Sub County, however in Homa Bay Town Sub County, the use was relatively high. While interviewing trader $\mathrm{A}$ in Ndhiwa town, the researcher established that Pay bill option of Safaricom's M-Pesa, was mainly used to remit monthly payment for National Hospital Insurance Fund (NHIF). Paybill made it easy for mobile phone users to remit their monthly medical insurance fee since; Banks were far in Ndhiwa town or Homa Bay. Other than mobile payment, the other option of remitting monthly is banks as explained by trader A;

"I know about pay bill, however only a few people use it. It is mainly used by those who pay their monthly 
NHIF contribution, since the other option of paying a bank is inconveniencing, and requires one to use transport to banks." "I have also seen some of the people who have installed electricity in their homes using this pay bill when paying electricity bills"

From the interview, it was becoming clear to the researcher, that in the rural communities, those who were economically well off were the ones using mobile phone money to pay for services and utility. Only those who could afford to install electricity in their homes as well as those who could afford NHIF insurance cover, who in deed were economically well off were the ones using the payment option.

Further, from observation, the researcher established that most of the mobile phone users who paid for services and utility bills in rural and urban settings were relatively educated. They were also relatively well-off economically as had been established through interview and FGD in Homa Bay Region.

\subsection{Buy Goods}

From observation, most of the people who frequently used money when buying good tended to be relatively young in age. Also those who preferred this service to pay for goods tended to be wealthier and educated. Therefore this mode of payment for goods purchased was more common in urban centers, than it is in rural communities. In Rangwe market center for example there was one trader who accepted mobile phone payment for their goods by customer. In Ndhiwa there were about four traders offering the same to their customers.

The researcher found out from trader A in Ndhiwa, who was among the traders who offered their customers option of mobile phone money payment for goods purchased, that most traders, especially in the rural community did not fully trust the technology;

"Payment done using Safaricom's M-Pesa till number is very tricky... You have to be really sure that the customer has paid you by confirming both the messages... the one in your phone and the other in the customer's phone if they tally up. If you are not keen you stand a chance of being forwarded a message that customer previously received, which may give you a huge loss, that is why most traders fear registering their businesses for mobile payment."

On the contrary, trader A, in the interview stated that most buyers, who tended to be educated, trusted mobile phone payment, as long as they till number mounted by the trader on the wall.

\section{Discussions}

Generally, the elements of mobile money services include; person-to-person transfer of funds, such as domestic and international remittances, person-to-business payments for the purchase of a range of goods and services and mobile banking through which customers can access their bank accounts, pay bills, or deposit and withdraw funds [10]. The researcher during the study established also the broad classifications of mobile money elements, similar to those identified by Dolan, namely, sending and receiving money, buying airtime, mobile banking, pay bill and buy goods.

According to Jack and Suri [11], one of the significant key influencers for mobile money deployment in developing countries have been the rise in remittance services both local and foreign and the provision of financial services to the rural unbanked. However much, mobile money is associated with mobile payments, the most significant achievement ever witnessed is on the person to person transfer of funds and the provision of banking services to the unbanked, either those in the rural or the urban poor as stated by Muwanguzi and Musambira [12].

The study established that most of the people in Ndhiwa and Rangwe Sub Counties that were characterized by rural poor attributes depended more on using mobile payment for remittance purposes. They used mobile payment to receive money from their relatives who lived and worked in urban areas, away from both Ndhiwa and Rangwe Sub Counties. This resonate well to, Safaricom's M-PESA initial usage, which was characterized by person-to-person money transfer from the urban workers to their families in the villages [12]. Similar case was also experienced in Philippines where, remittances to family members who lived in remote islands were done through Globe GCASH that was being used by over two million people [13]. This is an indication that using mobile payment majorly for remittances was not just common only to the study area which is Homa Bay region, or Kenya, but was as well common in other countries like Philipines.

The study found out that a number of elements of mobile phone money were already being used in the study area, with others being very common to rural and urban communities alike while others were only common to only urban communities. It was in Homa Bay Town Sub County where the usage of various mobile phone money elements were to a reasonable level compared to Ndhiwa and Rangwe. This trend is well justified by Ajzen and Fishbien's [14] theory of reasoned action, that puts it that, the subjective norm of a person is determined by whether people who are important to the person approve or disapprove of the performance of a behaviour (normative beliefs), weighted by the person's motivation to comply with those people important them [15]. The dominated use in urban parts of Homa Bay region was attributed to the approval of mobile phone money use by many, thereby creating completion-like when it came to adoption by the users. The rural parts of the study area still lacked approval of some of the mobile phone money elements, leading to the low using of all the varied elements of mobile phone money. 


\subsection{Sending and Receiving Money}

Sending and receiving money was the most common element of mobile phone money in the entire study area. In all the three sub counties that the researcher conducted the study namely Homa Bay Town, Rangwe and Ndhiwa, it was quite clear that this element was common to the youths as well as the old, to the rich as well as the poor, to the literate, as well the illiterate and to the people in the urban areas as well as the people in the rural areas. An interview conducted in Rangwe market center with a participant, found out that sending money to friends and relatives in other places as well as receiving money using mobile phone money was very common as can be seen from the words of the participant.

"This is the innovation that has really transformed how we go around our daily activities that revolves around sending and receiving money to and from others. In the past we would have to travel all the way to banks in Homa Bay Town to deposit cash for those who need it from us, or send as parcel to friends and relatives, which was really risky. Most of the people used to lose cash from time to time but when M-Pesa came, this has been a problem of the past... we just thank God for this"

An interview conducted in Homa Bay Town specifically, on the use of mobile phone to send money or receive money from friends and relative, showed popularity of the element. Just as it is stated in the Ajzen and Fishbien's [14] theory of reasoned action, the most accurate determinant of behaviour is behavioural intention and the direct determinants of people's behavioural intentions are their attitudes towards performing the behaviour and the subjective norms associated with the behaviour. This clearly came out from the statement by a participant in Rangwe market. Many people in the study area adopted the use of mobile phone money especially the element of sending and receiving money to and from friends and relatives. The technology offered the users better way of handling remittances over the previously used methods that to a greater extent were very risky.

This finding is similar to the one in a study conducted by Okoth [5] in Kenya on M-Pesa that established a number of factors on mobile phone use. First it established that, more than half of M-Pesa users use M-Pesa primarily to send and receive money. This is typically the same scenario of Homa Bay region. This therefore, means that the element of mobile phone money in this case is, as a means of sending and receiving money (remittance). The key elements of mobile money that Okoth's study established were remittance and saving money.

Further, FGDs conducted in all the three Sub Counties also established the same results as that obtained through interview or similar to that which Okoth established in his study in 2009 in Kenya. Mobile money, especially Safaricom's M-Pesa, had become very popular because of the sending and receiving money in users' perception. This is a similar case to another study by Morawczynski [6] citing
Safaricom's M-Pesa as being used for "livelihood strategies" and that such "strategies helped residents to cope with and recover from stresses and shocks." Morawczynski's study was based on the previous ethnographic mixed method surveys in Kibera with additional work in the village of Bukura in Western Kenya. Remittances via M-Pesa were found to typically flow from urban to rural, with peaks during planting seasons, when farming inputs were needed, harvest seasons when additional labor was needed, and the so called "hunger season", when food stocks run low. This was typical of the study area as well as indicated by the findings. Even though this study was based on ethnographic mixed method, it mainly focused on remittance via M-Pesa from urban to rural communities. This study also brought strongly the mobile money element of remittance.

The study also concurs with the findings of Jack and Suri [11] in a study where they provided evidence that access to mobile money services facilitates risk sharing by significantly reducing the transaction costs of remittances among family members and friends in Kenya. They found that households which subscribe to M-Pesa, Kenya's most popular mobile money service, were able to cushion themselves against consumption volatilities when struck by income shocks, by receiving remittances from a wide pool of members in their social networks. Majorly in Ndhiwa and Rangwe Sub Counties, many people depended on remittances in times of economic shocks. At the beginning of school days, a lot of remittances are received from relatives and friends who were working and living in the urban centers and sometimes those people who were living and working in foreign countries. This indicated that behavioural intention to use mobile phone money services was high, and the almost everyone in the study area who owned mobile phone, was using the element of sending and receiving money.

\subsection{Buy Airtime}

Buying airtime was found by the researcher mainly to be common in towns and urban centers, and not rural settings. In rural parts of Rangwe and Ndhiwa sub counties, the study established that very few people were aware that they could easily buy airtime for making calls, directly from their mobile phones when they had "money value" within their phones. A participant in Ndhiwa appeared more surprised when the researcher informed her that it was possible for her purchase airtime from her mobile phone directly as long as she was registered on any of the mobile phone money services available to customers in Kenya.

The researcher found this statement quite interesting; however, that was the position in most of the rural parts of the study area. FGDs that were done in the two sub counties namely Ndhiwa and Rangwe, had mixed reactions, with just a handful of participants being aware that they could actually buy airtime directly from their phones when they have mobile money in their phones. Others would rather opt to walk a couple of distance in search of a mobile phone money 
agent in order to withdraw; thereafter use the same withdrawn money to buy airtime.

The study established that mobile banking was common among the young generation, and the educated who tended to be wealthier. From observation, most of those who spoke positively about mobile banking were majorly in urban centers. Most of them were also relatively young in age.

The interview conducted established that mobile banking was much unpopular in the rural parts of Homa Bay Region. A participant for interview conducted in the remote part of Rangwe Sub County did not believe that his money could be safe when banked through mobile phone money. This is in contrary to how implementation of mobile infrastructure was foreseen to be more feasible for rural areas compared to traditional fixed line infrastructure implementations as it was envisioned; it would better serve a wider community in a more feasible option in terms of cost and maintenance [16]. For instance, as rural areas generally contained scattered populations, wireless networks would save on high costs of fixed line implementation services and improve network coverage over a wide area, thereby making mobile phone money services a financially viable solution in rural areas.

\subsection{Pay Bill}

Pay bill element was found to be in use in a lower scale in both Ndhiwa and Rangwe Sub County that were comprised of the rural setup. However in Homa Bay Town Sub County, which was more of an urban setup, the use was relatively high. The researcher established that Pay bill option of Safaricom's M-Pesa, was mainly used to remit monthly payment for National Hospital Insurance Fund (NHIF), but only by a few people who were living in the rural parts of the study area. To them who had embraced this mode of paying their monthly subscription towards their medical insurance cover, it was easier to use pay bill that to move to various urban centers where Banks and NHIF offices/branches exist. Looking at it from the perception of those who had been using this option for various option, it was clear that Pay Bill element had potential advantages, but only if it was adopted by the mobile phone users.

First it helps in eliminating unnecessary spending on transport to urban centers where users would be able access similar or exactly the same services to those offered by this platform.

Further, from the interview, it was clear to the researcher, that in the rural communities, those who were economically well off were mostly the ones using mobile phone money to pay for services and utilities over their economically less fortunate counterparts. Only those who could afford to install electricity in their homes as well as those who could afford NHIF insurance cover, who in deed were economically, well off and were the ones using this payment option. It is these categories of individuals who the various bills that could be met using pay bill payment option of a mobile phone payment. The researcher again established that, most of the mobile phone users who paid for services and utility bills in rural and urban settings were relatively educated, in addition to being relatively well-off economically as had been established through interview and FGD.

\subsection{Buy Goods}

From observation, most of the people who frequently used money when buying goods tended to be relatively young in age. Also those who preferred this service to pay for goods tended to be wealthier and educated. Therefore this mode of payment for goods purchased was more common in urban centers, than it was in rural communities. In Rangwe market center for example there was one trader who accepted mobile phone payment to receive payments of their goods by their customer. However, it was worth noting that, not all traders trusted this method of payments. Many therefore would always be suspicious of any payment being made to them through this platform. They would therefore resort to confirmation of any short message service (SMS) indicating payments in both the customers' mobile phone, as well as their phone, in order to be able to verify. On the contrary it was strange to the researcher that, at least some of the users trusted, this method of payment more that most of the traders in the study area. This method therefore was unpopular in the study area as a result of the understanding of traders in the area, more so with respect to offering customers with this kind of technology, as one other option of carrying out payment for the goods purchased.

This would help to a greater extent in making sure that the customers became secure from robbers and thugs that normally targeted customers who always had cash in their pockets, wallets and purse. The customers would no longer put their lives to more risk of walking with sums of money in cash in other platforms, mobile phone money being one of them.

\section{Conclusions}

In conclusion the study established that mobile phone money as it is currently is not a new phenomenon to any part of most society; whether rural or urban, whether users are literate or illiterate, whether users are wealthy or poor. The most commonly used element of mobile money is for sending and receiving cash (remittances) to and from friends and /or relatives. Other elements such as buying goods, paying bills and mobile banking were still unpopular. Mobile phone money, being a good technology especially, in bringing on board the rural, poor, unbanked community, mobile money need intensive sensitization on all aspects of its benefits, whether financial or social, for every potential user to have a clear picture of this innovation.

\section{REFERENCES}

[1] Hoofnagle, C. J., Jennifer M. \& Li, U.S., (2012). Mobile Payments: Consumer Benefits \& New Privacy Concerns: 
BCLT Research Paper April 24, 2012

[2] Mallat, N. (2007). Exploring Consumer Adoption of Mobile Payments. A Qualitative Study. The Journal of Strategic Information Systems, 16 (4), 413-432.

[3] Hernando, I., \& Nieto, M. J. (2006). Is the internet delivery channel changing banks' performance? The Case of Spanish Banks. Madrid, Madrid, Spain: Ban code Espana.

[4] Comninos A., Esselaar S., (2009). Airtime to Cash: Unlocking the Potential of Africa's Mobile Phones for Banking the Unbanked. IST Africa 2009, Uganda, IIMC.

[5] Okoth, J., (2009). Regulator gives M - PESA a clean bill of health. The Standard Newspaper, 27 January 2009.

[6] Morawczynski, O. (2009). Examining the Usage and Impact of Transformational M-Banking in Kenya. Internationalization, Design and Global Development. N. Aykin, Springer Berlin / Heidelberg. 5623: 495-504.

[7] Denzin, N. K. \& Lincoln (2011). The Sage Handbook of Qualitative Research. Sage Publications: USA.

[8] Iacono, J. Brown, A., \& Holtham, C., (2009). Research Methods - a Case Example of Participant Observation: Electronic Journal of Business Research Methods Volume 7 Issue 12009 (39 - 46)

[9] Myers, M.D. (1999) 'Investigating Information Systems with Ethnographic Research' in Communications of the AIS, Vol. 2, Article 23 pp. 1-20
[10] Dolan, J. (2009). Accelerating the Development of Mobile Money Ecosystems. Proceeding of MOBILE MONEY SUMMIT. Retrieved from http://www.microfinancegateway.org/gm/document1.9.5086 9/Mobile\%20Money\%20Summit\%202009.pdf

[11] Jack, W., \& Suri, T. (2011). Mobile money: the economics of M-PESA. NBER Working Paper No. 16721. National Bureau of Economic Research, Cambridge, MA.

[12] Muwanguzi, S., \& Musambira, G. W. (2009). The Transformation of East Africa's Economy Using Mobile Phone Money Transfer Services: A Comparative Analysis of Kenya and Uganda's Experiences. Journal of Creative Communications, 4(2), 131-146.

[13] Maurer, B. (2012). Mobile money: Communication, consumption and change in the payments space. Journal of Development Studies, 48(5), 589-604.

[14] Ajzen, I. \& Fishbein, M. (1980). Understanding Attitudes and Predicting Social Behavior. Englewood Cliffs, NJ, Prentice-Hall Inc.

[15] Montano, D. E. \& Kasprzyk, D. (2002). The theory of reasoned action and the theory of planned behaviour. In K. Glanz, B. K. Rimer, \& F. M. Lewis (Eds.), Health behaviour and health education: Theory, research and practice (pp. 67 98). San Francisco: Jossey Bass.

[16] Bazelon, C. (2010). "The Benefits of Wireless Broadband for Rural Deployments." Retrieved on 2 January, 2016, from http://www.brattle.com/_documents/UploadLibrary/Upload8 37.pdf. 